\title{
ATTENTIONAL DISORDERS IN PATIENTS WITH COMPLEX PARTIAL EPILEPSY
}

\author{
Florindo Stella', Jayme Antunes Macie/
}

\begin{abstract}
A study of concentrated attention patterns in epileptic patients was conducted with the objectives: characterization of the patients' epileptic condition; assessment of the concentrated attention levels in epileptic and nonepileptic individuals; comparison of the attention levels of the two groups. An evaluation was performed of 50 adult outpatients with complex partial seizures and 20 non-epileptic individuals (comparative group) at the Neuroepilepsy Ambulatory Unit, State University of Campinas SP, Brazil. Method: characterization of seizure types, frequency and duration; concentrated attention assessment (Concentrated Attention Test - ToulousePiéron); comparison of the epileptic with non-epileptic individuals. Results: A statistically significant difference was observed between the groups with regard to Correct Response, Wrong Response and No Response. A difference was observed in relation to Time, but it was statistically insignificant. The epileptic patients presented inferior cognitive performance in relation to concentrated attention when compared with the non-epileptic individuals, findings compatible with the clinical complaints.
\end{abstract}

KEY WORDS: neuropsychology, attention, complex partial epilepsy.

\begin{abstract}
Distúrbios de atenção em pacientes com crises parciais complexas
RESUMO - Estudou-se o padrão da atenção concentrada em pacientes epilépticos, com o objetivo de se caracterizar a condição epiléptica, avaliar os níveis de atenção concentrada em epilépticos e em sujeitos nãoepilépticos e comparar esses níveis entre os grupos. Foram avaliados 50 pacientes adultos com crises parciais complexas em atendimento no Ambulatório de Neuroepilepsia da Universidade Estadual de Campinas SP, Brasil. Também foram estudados 20 sujeitos sem epilepsia, para efeito comparativo. Método: caracterização tipológica, freqüência e duração das crises; avaliação da atenção concentrada (Teste de Atenção Concentrada - Toulouse-Piéron); e comparação dos resultados dos pacientes dos pacientes com os sujeitos não-epilépticos. Resultados: Houve diferença estatisticamente significativa entre ambos os grupos nos itens Acertos e Erros + Ausências. No item Tempo houve diferença, mas sem significância estatística. Os pacientes apresentaram desempenhos cognitivos inferiores nos padrões de atenção concentrada em comparação com os não-epilépticos, resultados esses compatíveis com as queixas clínicas.
\end{abstract}

PALAVRAS-CHAVE: neuropsicologia, cognição, atenção, epilepsia parcial complexa.

Attention is a complex neuropsychological process that has the function of facilitating conscious mental activity, choosing a stimulus from among many others and selectively responding to relevant stimuli in accordance with the needs of the organism ${ }^{1,2}$. An individual is able to process specific information from the large quantity of information that reaches the brain, mainly with the help of the sensory organs. Using the cognitive skill of stimulus selection, the individual is able to direct, maintain or modify the focus of consciousness ${ }^{3}$. This process is called selective attention. In maintaining control of selective information entry at any given moment into the cognitive system, the individual develops the mechanism of concentrated attention ${ }^{4}$, a phenomenon that is necessary for the learning process. The neuropsychology of the attentional process has long been a preoccupation of individuals who study cognitive function ${ }^{5-7}$.

Various areas in the brain and neuropsychological processes play a critical role in selective attention and maintenance of this cognitive activity with reticular formations, prefrontal cortical and parietal areas, cingulated gyrus and extensive cortical and

Neuropsychology and Behavior Neurology Unit, Department of Neurology, Faculty of Medical Sciences, State University of Campinas UNICAMP, Campinas SP, Brazil: ${ }^{1}$ Assistant Professor of Psychology, Institute of Biosciences, Paulista State University - UNESP, Campus of Rio Claro SP, Brazil; ${ }^{2}$ Associated Professor of Neurology, Department of Neurology, Faculty of Medical Sciences, UNICAMP, Campinas SP, Brazil. This study was supported by a research grant of FAPESP, São Paulo State Fondation of Research.

Received 6 June 2002, received in final form 20 November 2002. Accepted 3 December 2002. 
subcortical networks ${ }^{2,6,8,9}$. These areas and networks are able to regulate the concentration capacity and sustain a vigilance period as well as assess the disturbance that may affect the attentional process because of the internal and external conditions. Cognitive and attentional disorders, in particular, are often a part of neuropsychiatric disorders with different levels of severity depending on the location and extension of cortical and subcortical compromise ${ }^{10,11}$. Clinical conditions such as epilepsy with complex partial seizures (CPS) may be associated with changes in cognitive functions, one of them being attention ${ }^{10,11}$. Antiepileptic drugs also have been related to adverse effects on cognitive processes, including attention ${ }^{12,-14}$. Attentional disorders in epileptic patients, particularly those with CPS are not isolated phenomenon of mental activity but are concomitantly related with changes in other cognitive functions such as memory, thinking process course and structure, language and perceptive activity, as well as mechanisms of psychosocial interaction ${ }^{10,11,15,16}$.

The purpose of this research is to study the concentrated attention patterns in epileptic patients with CPS and to compare them with individuals without epilepsy or others neuropsychiatric disorders.

\section{METHOD}

Subjects - The study consisted of 50 epileptic patients of both sexes, ages ranging from 19 to 49 years and under treatment at the Neuroepilepsy Ambulatory Unit, Department of Neurology, FCM, UNICAMP, Campinas, SP.

The patients suffered from complex partial seizures that were either preceded by simple partial seizures or not and with or without secondary generalization. For comparative purposes, an assessment was performed of 20 non-epileptic individuals, free from other neuropsychiatric disorders and having similar sociocultural, occupational and educational characteristics.

Methodological Procedure - In order to characterize the clinical diagnosis and type of seizures, the patients went through the following stages: a) complete investigation of clinical history including data concerning seizure onset age; frequency and chronicity of the seizures; detailed characterization and classification of seizure type; b) free from epileptic manifestations a week before the examination; c) physical, neurological and psychiatric examination; d) complementary investigation: electroencephalography (EEG) to locate the epileptogenic area and define the nature of the altered bioelectric activity, neuroimaging and serology for the detection of possible etiological factors, serum dosage of medication, general laboratory examinations (hemogram, kidney functions and hepatic functions); e) psychiatric assessment utilizing a detailed clinical interview, the patient's clinical history and applying the Montgomery-Asberg Depression Scale ${ }^{17}$. Patients with a serum dosage incompatible with the therapeutic group were excluded. The psychiatric assessment aimed at identifying possible psychopathological conditions and excluding patients with psychiatric conditions as they may interfere in the quality of the patient's cognitive pattern. Various patients were excluded because of the presence of mental disorders, leaving 50 patients who participated in the study; f) the concentrated attention pattern was investigated by applying the Toulouse-Piéron Concentrated Attention Test, translated and adapted by Maciel ${ }^{18}$. This tool helps in the investigation of three sectors related to attention: indices of Correct Response, No Response + Wrong Response in executing the test and Time taken to complete the test. The results were statistically analyzed by applying the Mann-Whitney non-parametric test for the sectors Correct Response, No Response and Wrong Response in test execution and for the Time sector, the T-test was applied, besides the Mann-Whitney test. Statistical analysis was executed by the Research Commission, Faculty of Medical Sciences, State University of Campinas, UNICAMP. The participation of the patients and nonepileptic individuals in the study was voluntary and with informed consent.

\section{RESULTS}

The mean age of the 50 patients was 32 years 5 months and of the 20 control individuals was 36 years 4 months. The average educational period of the patients was 7 years 6 months and of the controls 7 years 4 months.

None of the 50 patients in the sample had neuropsychiatric conditions that impeded attention assesment: the neurological exam was normal, mental disorders that hamper attentional performance were absent and in accordance with the Montgomery-Asberg depression scale, depressive disorder indicators were absent. All the patients were on antiepileptic medication therapy according to their serum dosage.

The results of the Toulouse-Piéron Concentrated Attention Test administered to the 50 patients and 20 controls were the following: regarding the sector Time - the patients took an average of 727 seconds and the controls 683 seconds, revealing no significant difference between the groups according to the Mann -Whitney test and the T-test $(p=0.32)$; the Correct Response sector, the patients presented an average score of 189.3 and the controls a score of 207.7, demonstrating a significant difference between the groups according to the non-parametric Mann-Whitney test $(p=0.001)$; in the sector No response + Wrong Response, the average score obtained by the patients was 40.4 while the controls scored 13.4, a statistically significant difference according to the non- parametric Mann-Whitney test $(p=0.0015)$. In brief, when compared to the controls, 
the patients utilized, on an average, more Time to execute the attention test. The score for Correct Responses was inferior and for No Responses + Wrong Response was superior. The graph below demonstrates the Results (Fig 1).

\section{DISCUSSION}

Daily lapses of attention are common in the general population and on their own, do not represent compromise of the cognitive process ${ }^{19}$. Research studies link selective attention and concentrated attention, respectively, to the ability of the individual to establish a goal in order to direct mental activity and the capacity to maintain a level of alertness that helps the individual reject interferences that disturb mental action. Besides, the quality of attention linked to a defined stimulating source depends on the individual's quality of accuracy in detecting stimuli and the response rapidity to these stimuli20,21. Attention and changes in attention are better evaluated when the individual is subjected to complex tasks that demand a high level of cognitive performance ${ }^{4}$ as in specific test conditions.

The results indicated significant statistic difference between the performance of the patients in the concentrated attention test and that of the nonepileptic individuals regarding the sectors Correct response and No response + Wrong Response $(p<0.05)$. In the sector Time, a difference was observed between



Fig 1. Concentrated Attention Test (Toulouse-Piéron) in 50 CPS patients compared to 20 nonepileptic subjects. the two groups, but it wasn't statistically significant $(p>0.05)$. The attention difficulties detected by the test are compatible with the clinical complaints revealed by the patients during the clinical interview, which was an opportunity for them to report the difficulties they faced when performing cognitive tasks that demanded concentrated attention. The cognitive performance of the patients in this study was significantly inferior to that of the non-epileptic individuals and was in accordance with the studies conducted by other authors, revealing that epileptic patients with chronic alterations of cerebral bioelectric activity were more inclined to attention disorders ${ }^{22-24}$.

The quality of the patient's concentrated attention has probably been influenced by various factors such as the nature, duration and frequency of the seizures, extension and location of neuroanatomic or epileptogenic compromise and the use of medication. Besides the temporal regions of the brain, other regions also play a role in directing attention, such as the frontal lobe ${ }^{25}$, inferior portion of the parietal lobe ${ }^{26}$, the prefrontal region and the cingulated gyrus ${ }^{9}$. Nevertheless, the question of cerebral attention 'location' remains unanswered.

In this study, most of the patients with attention disorders presented epileptic seizures having a preponderant origin in the temporal region. This data on its own, certainly does not establish a link between temporal compromise and attention disorder.

From a systemic viewpoint, mutual influence of the mental processes is consensual as the brain behaves like an integrated unit despite its functionally specialized areas $^{7}$. Hence, neuropsychological performance would represent a unitary activity involving different interconnected networks responsible for mental functions, including attention ${ }^{6,7}$. On the other hand, attention disorders interfere in other cognitive processes, especially in the quality of learning, memorizing new information, consolidating learned content ${ }^{27,28}$ as well as in executive functions resulting from prefrontal cortex activity?

Attention disorders may also affect logical thinking, quality of perception and language capacity. This concept is corroborated by the fact that mental functions need extensive neurophysiological interconnection between the various cortical and subcortical areas as well as the intra-hemispheric and inter-hemispheric areas ${ }^{7}$.

Other problems that may interfere with the cognitive functions, including the attentional process, are depressive disorders ${ }^{4,29,30}$. To prevent the interfe- 
rence of this variable in the results of this study, besides the clinical interview, the Montgomery-Asberg depressive scale was also applied to detect depressive symptoms. The neurological assessment did not detect these symptoms in the 50 selected patients.

With regard to the Toulouse-Pieron Concentrated Attention Test, the authors reached the conclusion that the cognitive performance of the patients in this study was significantly inferior to that of the non-epileptic individuals and was probably related to their epileptic condition, manifested by complex partial seizures. Seizure related factors such as onset date, frequency, chronicity and medication probably interfere with attention and should be studied in detail. The influence of seizures other than complex partial seizures should also be investigated. Sociocultural, occupational and educational components may influence the cognitive performance, particularly attention, and therefore, these variables should be studied.

\section{REFERENCES}

1. Kolb B, Whishaw I. Fundamentals of human neuropsychology. 4. Ed. New York: W.H. Freeman and Company, 1996:691.

2. Aston-Jones GS, Desimone R, Driver J, Luck SJ, Posner MJ. Attention. In Zigmond MJ, Bloom FE, Landis SC, Robertis JL, Squire LR (eds). Fundamental neuroscience. San Diego: Academic Press, 1999:1385-1409.

3. Almeida OP, Kotynia R. Confusão mental e demência. In Botega NJ (ed). Prática psiquiátrica no hospital geral: interconsulta e emergência. Porto Alegre: ArtMed, 2002:176-191.

4. Cortese, SS, Mattos P, Bueno JR. Deficits atentivos e antidepressivos. J Bras Psiquiatria 1999;48:79-85.

5. Engelhardt E, Rozenthal M, Laks J Neuropsicologia VIII - Atenção: aspectos neuropsicológicos. Rev Bras Neurol 1996;32:101-106.

6. Posner M, Digirolamo G. Attention in cognitive neurosciences: an overview. In Gazzaniga D (ed). The new cognitive neurosciences. Cambridge: Mit Press, 1996: 623-631.

7. Kandel EP, Schwartz JH, Jessesl TM (eds). Attention focuses visual perception by facilitating coordination between separate visual pathways. In Essentials of neural science and behavior. Norwalk, Appleton \& Lange, 1995:401-403.

8. Mesulam MM. Neural substrates of behavior: the effects of focal brain lesions upon mental states. In Nicholi, A.M. (ed). The Harvard guide to psychiatry, 3. Ed. Cambridge: Harvard Univ Press, 1999:101-103.
9. Damásio, AR. Oerro de Descartes: emoção, razão e o cérebro humano. Trad.: Vicente D, Segurado G. São Paulo: Companhia das Letras, 2000:330.

10. Trimble MR. Epilepsy and behaviour. Epilep Res 1991;10:71-79.

11. Cummings J. Trimble M. R. Concise guide to neuropsychiatry and behavioral neurology. Washington, American Psychiatry Press Inc, 1995:272.

12. Benet T. (ed). Cognitive effects of epilepsy and anticonvulsivant medications. In the neuropsychology of epilepsy. New York: Plenum Press, 1992:73-95.

13. Martin R, Kuznieck R, HoS, etal. Cognitive effects of topiramate, gabapentin, and lamotrigine in young adults. Neurology 1999;55:321-327.

14. Sotero deMenezes MA, RhoJM, Murphy P, CheyetteS. Lamotrigine-induced tic disorder: report of five pediatric cases. Epilepsia 2000;41:862-867.

15. Artigas J. Implicaciones psicologicas y sociales de las epilepsias del adolescentes. Rev Neurol (Barc) 1999;28:43-49.

16. Stella F. Distúrbios de memória em pacientes epilépticos. Arq Neuropsiquiatr 1999;57:415-420.

17. Montgomery S, Asberg M. A new depression scale designed to be sensitive to change. Brit J Psychiatr 1979;134:382-389, Adaptação de Jayme Antunes Maciel. Campinas: Unidade de Neuropsicologia e Neurologia do Comportamento, Departamento de Neurologia, Faculdade de Ciências Médicas, Universidade Estadual de Campinas. 1991.

18. Maciel JA. Bateria de neuropsicologia: funções corticais.Campinas: Unidade de Neuropsicologia e Neurologia do Comportamento, Departamento de Neurologia, Faculdade de Ciências Médicas, Universidade Estadual de Campinas, 1991:25.

19. Manly T, Robertson, IH, Galloway M, Hawkins K. The absent mind: further investigations of sustained attention to response. Neuropsychologia 1999;37:661-670.

20. Mesulam MM. Principals of behavioral neurology. Phyladelphia: S.I. Davis Company, 1995:127-130.

21. Mesulam MM. Large-scale neurocognitive networks and distributed processing for attention, language, and memory. Ann Neurol 1990;28:597-613.

22. Espie CA, Paul A, McColl JH, et al. Cognitive functioning in people with epilepsy plus severe learning disabilities: a systematic analysis of predicts of daytime arousal and attention. Seizure 1999;8:73-80.

23. Rossi PC, Parmegiani A, Posar A, Senti S, Santucci M. Benign myoclonic epilepsy: long-term follow-up of 11 new cases. Brain Develop 1997; 19:473-479.

24. Neville BC. Reversible disability associated with epilepsy. Brain Develop, 1999;21:82-85.

25. Kim M, Na DL, Kim GM, Adair JC, Lee KH, Heilman KM. Ipsilesional neglect: behavioural and anatomical features. J Neurol Neurosurg Psychiatry 1999;67:35-38.

26. Driver J, Mattingley JB. Parietal neglect and visual awareness. Nature Neuroscience 1998;1:17-22.

27. Baxendale SA. The role of the hippocampus in recognition memory. Neuropsychologia, 1997;35:591-598.

28. Dulcan MK, Benson RS. Summary of the parameters for the assessment and treatment of children, adolescents, and adults with attention deficit and hyperactivity disorder. J Am Acad Child Adolesc Psychiatry 1997;36:1311-1317.

29. Channon S, Baker JE, Robertson MM. Working memory in clinical depression: an experimental study. Psychol Med 1993;23:87-91.

30. Brown RG, Scott LC, bench CY, Dohan RJ. Cognitive function in depression: its relationship to the presence and severity of intellectual decline. Psychol Med 1994;24:829-847. 